\title{
IANNIS XENAKIS
}

EONTA
for Brass and Piano
PITHOPRAKTA
for Orchestra
METASTASIS
for Orchestra
HERMA
Piano Solo

ST. 10 for Chamber Orchestra

STRATEGIE A Musical Game

AKRATA for Wind Instruments

ST. 4 for String Quartet

\section{BOOSEY \& HAWKES}

\section{Durham Twentieth Century Festival \& Summer School 1966}

20th - 27th August 1966. Jacques-Louis Monod, Henri Pousseur, Graham Treacher, John Alldis Choir, Susan Bradshaw, Josephine Nendick, Bruno Schrecker, Keith Puddy, Northern Sinfonia Orchestra.

Boris Brott, Malcolm Binns, Jeanne Loriod, New London Ensemble, Quatuor de l' O.R.T.F. Elizabeth Robinson, Ann Griffiths. Accommodation in Durham Castle. Festival concerts (run concurrently with the Summer School in the Great Hall of Durham Castle) and Summer School sessions and rehearsals devoted to representative works of all twentieth century schools of composition. Fee: 16gns. Details and brochures from: The Secretary, Music School, Palace Green, Durham. 


\section{Aaron Copland Piano Solo}

BILLY THE KID. (1938)

Excerpts from the Ballet, arranged by Lukas Foss ... $8 / 6$

DANCE PANELS (Ballet in seven sections) $1962 \quad 17 / 6$

DANZÓN CUBANO. (1942) Arranged by Leo Smit 10/-

DOWN A COUNTRY LANE. (1962)

FANTASIA MEXICANA

After El Salón México, adapted by Johnny Green $\quad 3 / 6$

FOUR PIANO BLUES. (1948) 10/-

OUR TOWN. (1940) Three pieces from the film score $8 / 6$

PIANO FANTASY. (1957) I5/-

PIANO SONATA. (194I) $15 /-$

PIANO VARIATIONS. (1930)

RODEO (Ballet in one act). (1942) 10/-

EL SALÓN MÉXICO. (1936)

Arranged by Leonard Bernstein $\quad 8 / 6$

Boosey \& Hawkes

\section{Rudall, Carte and Co. Ltd.}

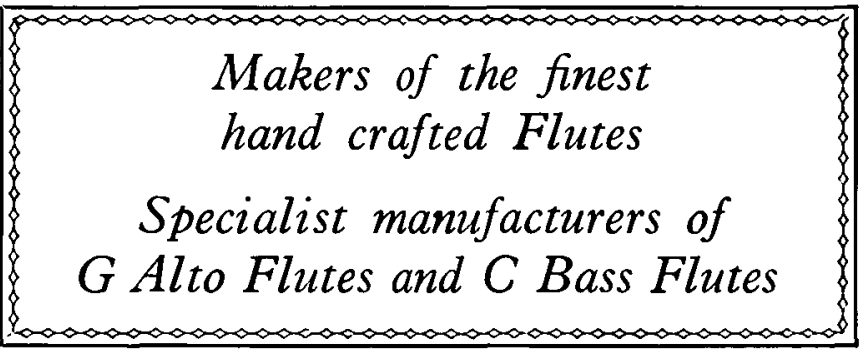

Brochure and "Approach to the Flute" by Mr. Geoffrey Gilbert on request

\section{8-10 DENMAN ST., PICCADILlY GIRCUS, LONDON W.1. GERRARD 1648}

